\title{
PENERAPAN MODEL GUIDED DISCOVERY LEARNING DENGAN MIND MAPPING UNTUK MENINGKATKAN KREATIVITAS MAHASISWA
}

\author{
Alfiani Athma Putri ${ }^{1}$, Reni Dwi Susanti ${ }^{2}$, Mayang Dintarini ${ }^{3}$ \\ ${ }^{1}$ Program Studi Pendidikan Matematika FKIP Universitas Muhammadiyah Malang \\ alfi_rosyadi@yahoo.com \\ ${ }^{2}$ Program Studi Pendidikan Matematika FKIP Universitas Muhammadiyah Malang \\ RenyDwy21@gmail.com \\ ${ }^{3}$ Program Studi Pendidikan Matematika FKIP Universitas Muhammadiyah Malang \\ mayangdintarini@gmail.com
}

\begin{abstract}
The aim of this research is to describe the aplication of guided discovery learning model with mind mapping that could increase students creativity in compiling thesis proposal. The approach of this research is descriptive qualitative with the research subjects are 3rd grade students of Mathematics study program of UMM that taking Research Metodology course.

The steps of this research are planning, implementation, analysis, and evaluation respectively. The Guided discovery Model Learning with Mind Maping is applied at the implementation stage, where students are required to develop research proposals based on guided discovery learning steps, that is (1) provision of stimuli, (2) problem identification, (3) completion data, (4) data processing, (5) verification, and (6) generalizations, which have been compiled in textbooks of Research Methodology courses. The results of this research found that students have difficulties in determining the topic of research, the reference, and the types of the research and instruments to be used.
\end{abstract}

Keywords: guided discovery learning, mind mapping, creativity

\section{PENDAHULUAN}

Proses pembelajaran dipengaruhi oleh beberapa aspek antara lain internal dan eksternal. Faktor internal itu sendiri meliputi dosen, mahasiswa, media pembelajaran, dan metode pembelajaran. Sedangkan faktor eksternal meliputi kondisi kelas dan aspek yang ada pada lingkungan luar. Adapun faktor internal yang mempengaruhi antara lain keaktifan mahasiswa, semangat, hasil belajar mahasiswa dan kreativitas mahasiswa.

Menurut Torrance dalam Bart dkk (2015) kreativitas adalah kemampuan untuk merasakan masalah, membuat tebakan, menghasilkan ide baru dan mengkomunikasikan hasilnya. Kreativitas belajar merupakan salah satu indikator keberhasilan mahasiswa dalam belajar yang memegang peranan penting dalam pencapaian keberhasilan pembelajaran. Mahasiswa yang kreatif selalu ingin memecahkan persolan-persoalan, berani menanggung resiko yang sulit sekalipun, kadang-kadang destruktif di samping konstruktif, lebih senang bekerja sendiri dan percaya pada diri sendiri.

Rogers mendefinisikan kreativitas sebagai proses munculnya hasil-hasil baru ke dalam suatu tindakan (Munandar, 1992). Hasil-hasil baru itu muncul dan sifat-sifat individu yang unik yang berinteraksi 


\section{Penerapan Model Guided Discovery Learning Dengan Mind Mapping Untuk Meningkatkan Kreativitas Mahasiswa \\ Alfiani Athma Putri, Reni Dwi Susanti, Mayang Dintarini}

dengan individu lain, pengalaman, maupun

keadaan hidupnya. Kreativitas ini dapat terwujud dalarn suasana kebersamaan dan terjadi bila relasi antar individu ditandai oleh hubungan-hubungan yang bermakna. Kreatifitas itu sendiri dipengaruhi oleh empat aspek: a) fluency, b) fleksibility, c) originality, dan d) novelty. Untuk menghasilkan ide-ide baru dalam suatu pembelajaran diperlukan suatu model pembelajaran yang sesuai, salah satunya yaitu guided discovery learning. Guided discovery learning sangat diperlukan oleh mahasiswa. Menurut Eggen \& Kauchak (2012: 177) model guided discovery learning (temuan terbimbing) adalah satu pendekatan mengajar dimana dosen memberi mahasiswa contoh-contoh topik spesifik dan memandu mahasiswa untuk memahami topik tersebut. Kelebihan dari model guided discovery learning, yaitu: (a) pengetahuan ini dapat bertahan lama, mudah diingat dan mudah diterapkan pada situasi baru, (b) meningkatkan penalaran, analisis dan keterampilan mahasiswa memecahkan masalah tanpa pertolongan orang lain, (c) meningkatkan kreatifitas mahasiswa untuk terus belajar dan tidak hanya menerima saja, (d) terampil dalam menemukan konsep atau memecahkan masalah.

Konsep yang ditemukan melalui guided discovey learning dapat dikolaborasikan dengan mind mapping. Mind mapping berasal dari bahasa inggris, yaitu dari kata mind dan mapping yang masing-masing adalah mind berarti otak, dan mapping berarti memetakkan. Menurut Buzan (2012:4) “Mind Map adalah cara termudah untuk menempatkan informasi kedalam otak dan mengambil informasi dari luar otak. Mind Map adalah cara mencatat yang kreatif, efektif, dan secara harfiah akan memetakan pikiran-pikiran kita". Mind mapping juga merupakan peta rute yang hebat bagi ingatan, memungkinkan kita menyusun fakta dan pikiran sedemikian rupa sehingga cara kerja alami otak dilibatkan sejak awal.

Metodologi penelitian adalah salah satu matakuliah yang diberikan pada semester $\mathrm{V}$ dengan tujuan untuk memudahkan mahasiswa dalam menyusun skripsi. Capaian pembelajarannya adalah mahasiswa diharapkan dapat mengidentifikasi keterkaitan antara ilmu dan penelitian, mengidentifikasi kaidahkaidah pokok penelitian sejak merumuskan masalah sampai menganalisis data, mampu menerapkan kaidah-kaidah tadi dalam kegiatan penelitian mulai menyusun rumusan masalah sampai menentukan analisa data yang akan digunakan, mengidentifikasi kaidah, dan menjelaskan cara mengkomunikasikan hasil penelitian.

Berdasarkan observasi pada tanggal 13 September 2016 - 4 Oktober 2016 diperoleh data bahwa mahasiswa mengalami kesulitan dalam menemukan ide ide yang layak diangkat sebagai masalah 
penelitian, mahasiswa juga sulit menuangkan konsep atau materi yang dibahas (metodologi penelitian) dalam proposal penelitian yang akan disusun. Selain itu mahasiswa juga belum terbiasa menyampaikan ide-ide dalam bentuk tulisan.

Banyak penelitian terkait kreativitas siswa dalam matematika, salah satunya adalah penelitian yang dilakukan oleh Bolden dkk (2009), yang bertujuan untuk mengeksplor kreativitas siswa di Inggris dalam matematika. Peneltian lain berasal dari Shriki (2009) yang menggambarkan pengalaman dari kelompok 17 calon guru matematika yang terlibat dalam serangkaian kegiatan yang bertujuan untuk mengembangkan kesadaran mereka tentang kreativitas dalam matematika. Selain tentang kreatifitas, adapula penelitian tentang Guided discovery Learning oleh Mayer (2004) menyatakan berdasarkan tiga penelitian yang dilakukan dalam tiga bidang yang berbeda (aturan pemecahan masalah,

strategi konservasi, dan konsep pemrograman) pure discovery learning tidak sesuai apabila diterapkan didalamnya. Hal ini disebabkan walaupun pure discovery memuat banyak tugas dan diskusi kelompok, namun gagal dalam mengedepankan proses kognitif yang pertama, yaitu memilih informasi yang relevan. Lebih singkatnya, ketika siswa diberikan terlalu banyak kebebasan, siswa mungkin gagal dalam membuat keterkaitan dengan materi yang akan dipelajari. Berdasarkan permasalahan di atas, penulis tertarik untuk mengangkat judul Penerapan Model Guided discovery Learning dengan Mind mapping untuk Meningkatkan Kreativitas Mahasiswa. Rumusan masalah penelitian ini adalah bagaimana penerapan model Guided discovery Learning dengan Mind mapping dalam meningkatkan kreativitas mahasiswa? Dengan tujuan penelitian yaitu untuk mendeskripsikan penerapan model Guided discovery Learning dengan Mind mapping dalam meningkatkan kreativitas mahasiswa.

\section{METODE PENELITIAN}

Penelitian ini menggunakan pendekatan deskriptif kualitatif. Subyek yang digunakan dalam penelitian ini adalah mahasiswa semester V UMM Program Studi Pendidikan Matematika yang sedang menempuh matakuliah Metodologi Penelitian.

Langkah-langkah penelitian yang dilakukan yaitu mulai dari perencanaan penelitian, pelaksanaan tindakan, analisis, serta evaluasi kegiatan. Adapun langkahlangkah penelitian yang dilakukan dalam penelitian ini dijabarkan dalam bagan di bawah ini. 


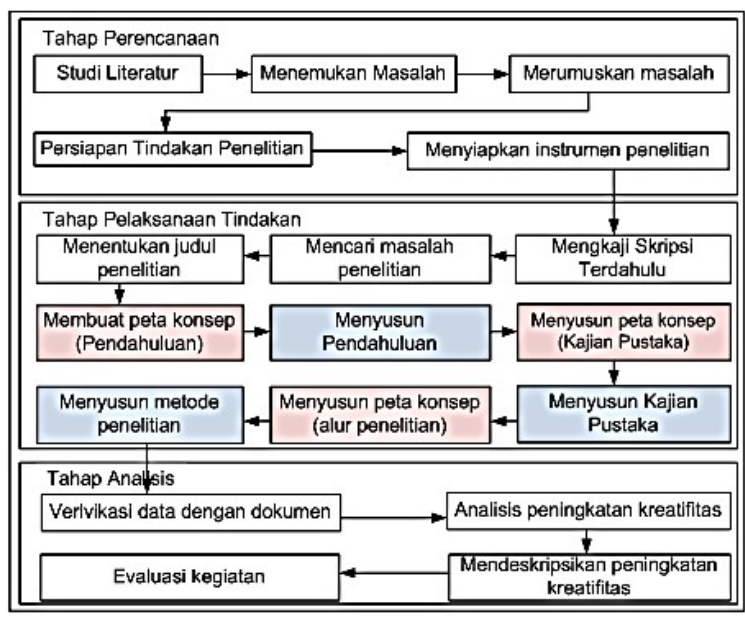

Bagan 1. Langkah-langkah Penelitian

Teknik pengumpulan data yang digunakan untuk mengumpulkan data keterlaksanaan kegiatan pembelajaran adalah observasi, observasi dilakukan oleh dua observer. Observer bertugas melihat berapa persen dosen model menerapkan Guided discovery Learning dan Mind mapping pada perkuliahan serta mencatat atau menuliskan penemuan maupun kegiatan selama penelitian berlangsung. Sedangkan untuk mengumpulkan data kreativitas, peneliti melakukan penugasan kepada mahasiswa untuk membuat peta konsep dan proposal penelitian. Fokus penelitian ini untuk aspek kreatifitas yaitu pada aspek originality dan flexibility. Adapun indikator kreativitas yang akan diteliti adalah sebagai berikut:

Tabel 1. Indikator Kreativitas

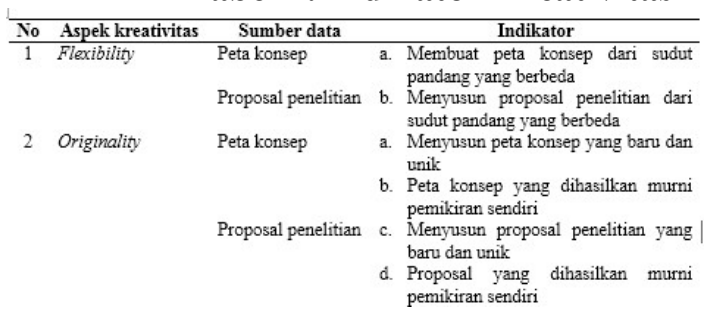

\section{HASIL DAN PEMBAHASAN}

Penelitian dilaksanakan secara kontinu selama perkuliahan Metodologi Penelitian berlangsung, dimulai dari pertemuan ke-5 sampai dengan pertemuan ke-14. Hasil observasi dan hasil dari tugas akhir pembuatan proposal dari mata kuliah metodologi penelitian adalah:

1. Pemberian Stimulus

Pemberian stimulus yang dimaksud dalam hal ini adalah memberikan pengarahan pada mahasiswa tentang apa yang harus mahasiswa kerjakan dalam proses penyusunan proposal. Akan tetapi mahasiswa kesulitan dalam menentukan topik apa yang akan di kaji. Mahasiswa hanya beracuan pada beberapa judul penelitian yang sering mahasiswa tersebut ketahui. Mahasiswa mempunyai kelemahan kurangnya minat membaca dan mencari referensi untuk topik penelitian.

2. Mengidentifikasi masalah

Proses mengidentifikasi masalah dalam penyusunan proposal ini terdiri dari dua tahap, yaitu tahap pembuatan mind maping dan tahap penyusunan isi proposal. Dalam hal pembuatan mind maping mahasiswa terlihat mengalami kendala dalam menentukan variabel apa yang akan mereka gunakan dalam mind maping sehingga mind maping yang mahasiswa buat sebagian besar hanya 
berisi gambaran dari penelitian yang secara umum.

Sedangkan dalam identifikasi masalah pada penyusunan proposal, untuk bab Pendahuluan yang merupakan ulasan penjelasan dari masalah yang akan diteliti. Dimana pada pendahuluan memuat teori pendukung, isu-isu terkini terkait dengan masalah yang akan dikaji, penelitian terdahulu dan alasan memilih masalah. Berdasarkan hasil dari observasi diperoleh data bahwa untuk bab pendahuluan mahasiswa cenderung mengalami kesulitan dalam hal menghubungkan tema yang sedang dikaji dengan isi pada pendahuluan. Dalam menentukan apa yang akan dituliskan pada pendahuluan, mahasiswa sering kali menuliskan hal yang berbeda atau diluar dari tema yang sedang di kaji.

Selain menentukan isi dari tema yang akan dikaji yang mengalami kesulitan, dalam hal menambahkan isu-isu terkait dengan tema yang akan di kaji. Mahasiswa sering tidak menambahkan isu-isu terbaru terkait dengan tema yang sedang dikaji. Mahasiswa sering kali hanya menuliskan teori pendukung dan alasan memilih masalah yang sedang dikaji. Dalam menuliskan isuisu terkait dan penelitian terdahulu sering tidak di lakukan oleh beberapa mahasiswa. Hal tersebut dilakukan dengan alasan bahwa mahasiswa merasa kesulitan dalam mencarinya.

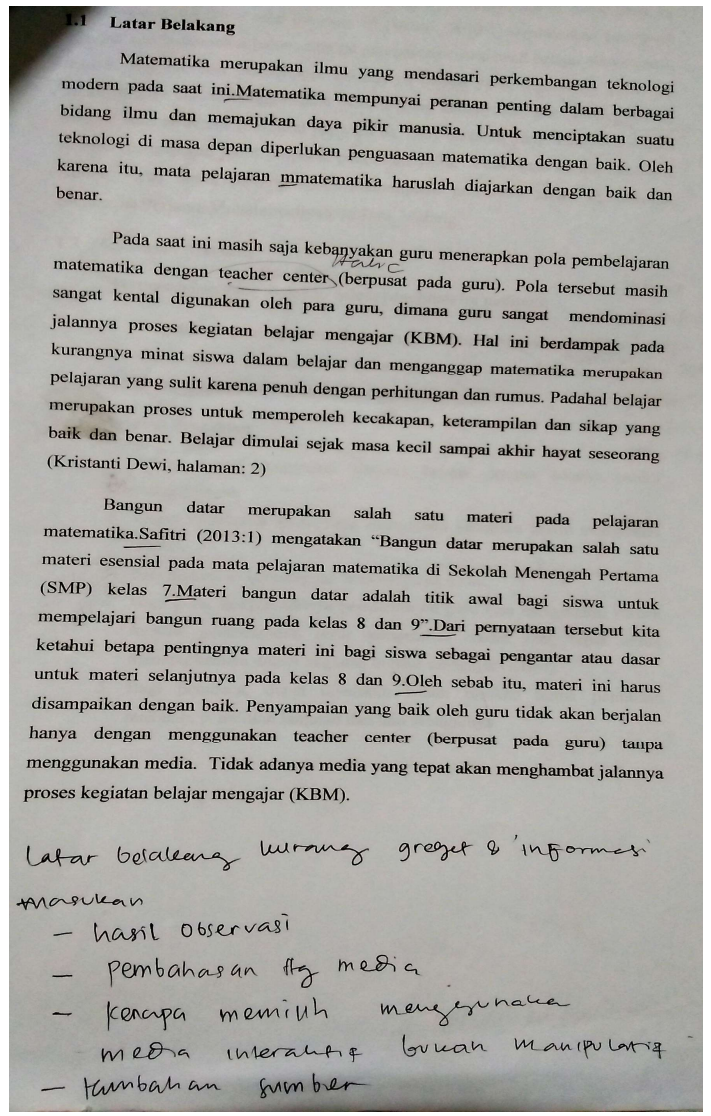

Gambar 1. Contoh Latar Belakang yang disusun Mahasiswa

3. Mengumpulkan data

Mengumpulkan data dalam penyusunan proposal dilakukan mulai dari menganalisis masalah untuk menentukan variabel-variabelnya, menentukan referensi untuk menyusun kajian pustaka sampai pada metodologi penelitian untuk menentukan jenis penelitian hingga analisis data apa yang akan digunakan dalam penelitian tersebut. Namun dalam penyusunan proposal penelitian, dalam kajian pustaka merupakan tahap yang paling sulit dalam mengumpulkan data terutama referensi atau buku sumber yang akan dijadikan sebagai dasar untuk melakukan penelitian tersebut. 


\section{Penerapan Model Guided Discovery Learning Dengan Mind Mapping Untuk Meningkatkan Kreativitas Mahasiswa \\ Alfiani Athma Putri, Reni Dwi Susanti, Mayang Dintarini}

Kajian pustaka merupakan hal yang menjadi dasar dalam penelitian. Dengan kajian pustaka yang jelas maka penelitian tersebut dapat di pahami kemana arah dan tujuan dari penelitian tersebut. Dalam menyusun kajian pustaka mahasiswa mengalami kesulitan untuk mencari referensi terbaru atau yang kurang lebih lima tahun terakhir. Berdasarkan hasil dari tugas penyusunan proposal diperoleh data bahwa hampir semua mahasiswa menuliskan kajian pustaka dengan menggunakan referensi yang lebih dari lima tahun terakhir. Faktor yang mendasari hal tersebut adalah karena mahasiswa tersebut kurang membaca dan cenderung untuk malas membaca dan mencari referensi yang terbaru.

4. Pengolahan data

Langkah pengolahan data ini adalah langkah dimana setelah mahasiswa mengidentifikasi masalah yang akan dikaji dan mengumpulkan sumber atau referensi apa yang akan digunakan. Pengolahan data banyak dilakukan pada penyususnan kajian teori dan penyusunan metode penelitian. Kajian pustaka pada proposal penelitian selain mahasiswa menggunakan referensi terbaru yang sangat kurang, dalam menuliskan kajian teori tersebut mahasiswa hanya menuliskan teori pada kajian secara umum. Mahasiswa tidak menuliskan kajian teori secara spesifik pada teori yang digunakan. Peran serta mind map yang bertujuan membantu dalam penulisan kajian teori tidak digunakan oleh mahasiswa sebagai acuan menyusun kajian teori. Berdasarkan hasil observasi, mahasiswa tersebut tidak bisa menspesifikasikan teori yang digunakan sebenarnya adalah teori yang bagaimana.

Disamping penyusunan kajian teori, langkah selanjutnya pada tahap penyusunan proposal adalah menentukan metode penelitian yang akan digunakan selama kegiatan penelitian berlangsung. Dengan metode penelitian yang runtut dan jelas maka dapat dikatakan bahwa penelitian tersebut terstruktur dan jelas alurnya. Hasil dari observasi di kelas dan berdasarkan tugas penyusunan proposal mahasiswa, didapatkan bahwa pada bab menuliskan metode penelitian mahasiswa menuliskan jenis penelitian tidak sesuai dengan judul dan tujuan penelitian yang sedang dikaji. Mahasiswa menentukan jenis penelitian hanya berdasarkan apa yang mereka baca dari penelitian-penelitian sebelumnya tanpa melihat dari rumusan apa yang sedang mahasiswa tersebut kaji.

Jenis penelitian yang jelas juga akan mempengaruhi pada apa yang akan di ukur atau di kaji dalam penelitian tersebut. Oleh karena itu alat 
ukur atau instrumen dalam penelitian menjadi salah satu hal yang sangat penting. Instrumen penelitian diharapkan mampu mengukur apa tujuan dari penelitian tersebut. Namun hasil observasi menunjukkan bahwa instrumen penelitian yang disusun oleh mahasiswa tidak sesuai dengan apa yang seharusnya mereka ukur dalam penelitian tersebut. Mahasiswa membuat instrumen hanya sekedar melihat dan mengambil dari penelitian terdahulu tanpa melihat indikator apa saja yang akan diukur dan indikator apa saja yang ada pada instrumen yang ada pada penelitian terdahulu tersebut. Kesalahan lain yang dilakukan oleh mahasiswa dalam menentukan instrumen penelitian misalnya yaitu dalam penelitian tersebut dibutuhkan lembar observasi atau wawancara namun dalam proposal yang dibuat tersebut mahasiswa tidak mencantumkan lembar observasi serta lembar wawancara dan sebaliknya.

Seiring dengan kesulitan mahasiswa dalam menentukan jenis penelitian yang digunakan, maka dalam menentukan analisis data juga banyak mengalami kesalahan. Menentukan analisis data, mahasiswa seharusnya melihat dari variabel apa yang digunakan dalam penelitian tersebut. Sehingga untuk menentukan kapan analisis data menggunakan kuantitatif menggunakan kualitatif. Metode penelitian akan mudah di susun ketika jenis penelitian yang akan digunakan sesuai dengan rumusan masalah yang akan dikaji. Rumusan masalah yang sudah spesifik dan mempunyai variabel yang jelas dapat mempermudah dalam menentukan jenis penelitian, prosedur, instrumen sampai pada menentukan analisis data yang sesuai.

Hasil tugas akhir penyusunan proposal mahasiswa sebagian besar menggunakan penerapan model atau metode pembelajaran, namun di dalam prosedur penelitian mahasiswa banyak menggunakan penelitian tindakan kelas. Sedangkan secara garis besar penerapan dan penelitian tindakan kelas merupakan dua hal yang berbeda.

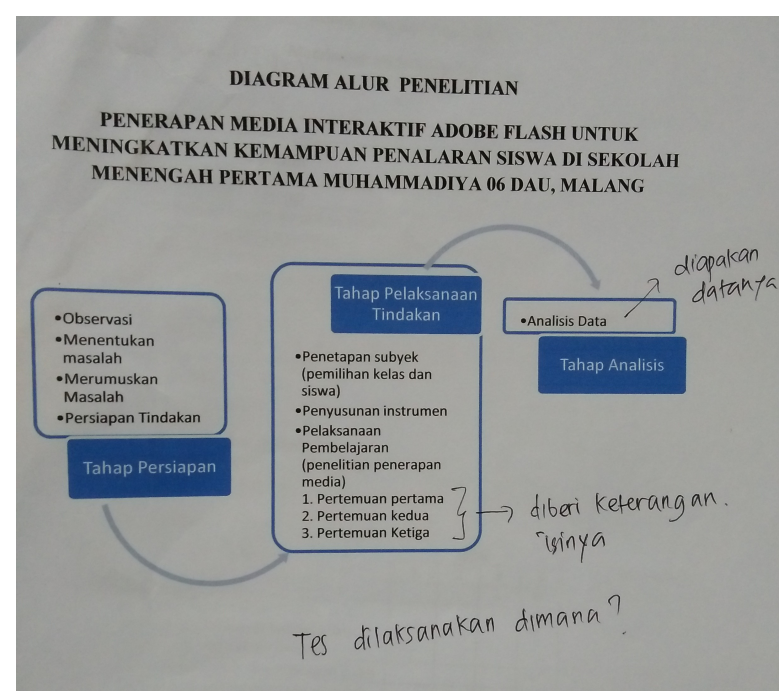

Gambar 2. Contoh Diagram Alir yang disusun Mahasiswa

Berdasarkan beberapa permasalahan tersebut dapat di katakan bahwa mahasiswa secara konseptual mempunyai kesulitan dalam 


\section{Penerapan Model Guided Discovery Learning Dengan Mind Mapping Untuk Meningkatkan Kreativitas Mahasiswa \\ Alfiani Athma Putri, Reni Dwi Susanti, Mayang Dintarini}

menentukan topik penelitian dan secara

prosedural mahasiswa mengalami

kesulitan dalam menentukan sumber atau refersensi serta menentukan jenis dan instrumen apa yang akan digunakan dalam penelitian tersebut. Hal ini disebabkan karena mahaiswa mempunyai kelemahan dalam hal membaca dan mencari sumber yang relefan sehingga keterbatasan mahasiswa dalam pengetahun tentang isi dalam proposal penelitian. Aspek kreativitas untuk Flexibility dan Originality memang sudah dilakukan oleh mahasiswa hanya saja terdapat beberapa permasalahan yang dialami.

\section{KESIMPULAN}

Kesimpulan yang dapat diambil adalah mahasiswa secara konseptual mempunyai kesulitan dalam menentukan topik penelitian dan secara prosedural mahasiswa mengalami kesulitan dalam menentukan sumber atau refersensi serta menentukan jenis dan instrumen apa yang akan digunakan dalam penelitian tersebut. Hal ini disebabkan karena mahaiswa mempunyai kelemahan dalam hal membaca dan mencari sumber yang relefan sehingga keterbatasan mahasiswa dalam pengetahun tentang isi dalam proposal penelitian. Aspek kreativitas untuk Flexibility dan Originality memang sudah dilakukan oleh mahasiswa hanya saja terdapat beberapa permasalahan yang dialami.

\section{REFERENSI}

Bart, W. M., Hokanson, B., Sahin, I., \& Abdelhady, M. 2015. An investigation of the gender differences in creative thinking abilities among 8th and 11th grade students §. Thinking Skills and Creativity, 17, 17-24. http://doi.org/10.1016/j.tsc.201 5.03.003.

Buzan, T. 2012. Buku Pintar Mind Map. Jakarta: PT Gramedia Pustaka Utama

Bolden, D. S., Harries, T. V, \& Newton, D. P. (2010). Pre-service primary teachers' conceptions of creativity in mathematics, 143157. http://doi.org/10.1007/s10649009-9207-z

Eggen, P. \& Kauchak, D. 2012. Strategi dan Model Pembelajaran. Jakarta: PT Indeks Mayer, R. E. (2004). Should There Be a Three-Strikes Rule Against Pure The Case for Guided Methods of Instruction, 59(1), 14-19. http://doi.org/10.1037/0003066X.59.1.14

Shriki, A. 2009. Working like real mathematicians: developing prospective teachers awareness of mathematical creativity through generating new concepts, 159179.

http://doi.org/10.1007/s10649009-9212-2

Mundandar, U. 1992. Mengembangkan Bakat dan Kreativitas Anak Sekolah. Jakarta: Gramedia Widiasarana Indonesia. 